\title{
PENGARUH STRES KERJA DAN BEBAN KERJA TERHADAP KINERJA SKPD KABUPATEN SINTANG KALIMANTAN BARAT
}

\author{
Niken Widyastuti (widyastuti_niken@ymail.com) \\ Fakultas Ekonomi Manajemen STIE Widya Wiwaha
}

\begin{abstract}
The purpose of this study is to determine the effect of stress at work and workload the performance as partial and simultaneous toward to SKPD performance in Kabupaten Sintang Kalimantan Barat. This study had used Descriptive Quantitative methode as main methode and Exhaustive Sampling as sampling methode. Sample were taken as a whole from thepopulation, that is 75 employees. Data were taken by using list of question, interviews, and literature searching. Data were analyzed by using Regression Methode and through SPSS program for Windows. The result of the study have shown that stress at work and workload significantly influence the employee's performance, with value of determintation was 0,681 or 68,1\%. Stress at work and workload had significantly influencing employee's to SKPD performance in Sintang Kalimantan Barat. For the next study, all considered, would be better if the next researcher added another variables that maybe had some contribution in employee's performance, such as working satisfication, neighbourhood, culture in work, reward, compensation and personality.
\end{abstract}

Key word:Stress at Work, Workload, and Employee's Performance of SKPD

\section{PENDAHULUAN}

Kinerja yang dicapai oleh suatu organisasi pada dasarnya adalah prestasi para anggota organisasi itu sendiri, mulai dari tingkat atas sampai pada tingkat bawah. Konsep kinerja pemerintah daerah sendiri muncul ketika institusi pemerintahan mulai mencoba mengenalkan konsep baru dalam pengelolaan urusan publik menjadi good governance. Organisasi yang berhasil merupakan organisasi yang memiliki visi dan misi yang jelas serta terukur. Artinya bahwa visi dan misi tidak akan bermakna ketika tidak teraktualisasikan dalam kinerja organisasi dalam kerangka menciptakan good governance. Oleh karena itu, kinerja merupakan the ultimate goals dalam setiap organisasi publik. Visi dan Misi itu sendiri mencerminkan komitmen organisasi secara teori dan diharapkan mampu diwujudkan dengan kinerja organisasi yang baik. Menurut Kumorotomo (2005:103), kinerja organisasi publik adalah hasil akhir (output) organisasi yang sesuai dengan tujuan organisasi, transparan dalam pertanggungjawaban, efisien, sesuai dengan kehendak pengguna jasa informasi, visi dan misi organisasi, berkualitas, adil, serta diselenggarakan dengan sarana dan prasarana yang memadai.

Perkembangan ilmu pengetahuan dan teknologi yang sangat pesat, membawa perubahan dalam kehidupan manusia. Perubahan -perubahan itu mengakibatkan tuntutan yang lebih tinggi terhadap setiap individu untuk lebih meningkatkan kinerja mereka sendiri. Adanya perkembangan tersebut, mengakibatkan pegawai harus mengubah pola dan sistem kerjanya sesuai dengan tuntutan yang ada sekarang. Dalam kehidupan modern yang makin kompleks, manusia akan cenderung mengalami stres 
apabila ia kurang mampu mengadaptasikan keinginan dengan kenyataan yang ada, baik kenyataan yang ada di dalam maupun di luar dirinya. Segala macam bentuk stres pada dasarnya disebabkan oleh kekurang mengertian manusia akan keterbatasannya sendiri. Ketidakmampuan untuk melawan keterbatasan inilah yang akan menimbulkan frustrasi, konflik, gelisah, dan rasa bersalah yang merupakan tipe-tipe dasar stres (Luthan, 2006: 439). Akibat - akibat stres terhadap seseorang dapat bermacam - macam dan hal ini tergantung pada kekuatan konsep dirinya yang akhirnya menentukan besar kecilnya toleransi orang tersebut terhadap stres.

Stres yang dialami oleh karyawan akibat lingkungan yang dihadapinya akan mempengaruhi kinerjanya, sehingga manajemen perlu untuk meningkatkan mutu lingkungan organisasional bagi pegawainya. Dengan menurunnya stres yang dialami pegawai tentu akan meningkatkan kesehatan dalam tubuh organisasi. Stres merupakan sebuah kondisi di mana seseorang dihadapkan pada konfrontasi antara kesempatan, hambatan, atau permintaan akan apa yang dia inginkan dan hasilnya dipersepsikan tidak pasti dan penting.

Selain itu, beban kerja yang merupakan sekumpulan atau sejumlah kegiatan yang harus diselesaikan oleh suatu unit organisasi atau pemegang jabatan dalam jangka waktu tertentu juga akan berpengaruh terhadap kinerja pegawai (Endang Hendrayanti, 2003). Beban kerja adalah sesatu yang terasa memberatkan, barang-barang atau sesuatu bawaan yang dipikul, yang sukar untuk dikerjakan sebagai tanggungan (M. B. Ali, 2002: 63). Beban berarti tanggungan yang harus dikerjakan sebagai tanggungan yang menjadi tanggung jawabnya.

Kinerja karyawan akan menentukan kinerja perusahaan dan untuk meningkatkan kinerja karyawan, maka perlu dihindari terjadinya stres kerja karyawan karena beban kerja yang terlalu tinggi, menurut Tuten dan Neidermeyer (2004) dalam Ma et al., (2012:6) yang akan mengakibatkan pada penurunan kinerja.

SKPD Kabupaten Sintang Kalimantan Barat, mempunyai komitmen untuk meningkatkan pelayanan publik dengan memperhatikan tuntutan dan dinamika masyarakat dalam suasana demokratisasi, desentralisasi, dan otonomi daerah. Organisasi publik dituntut adanya produktifitas kerja yang tinggi untuk mencapai tujuan kerja.

Di dalam suatu organisasi sebagai seorang pimpinan, mengelola stres lebih bersifat pemahaman akan penyebab stres orang lain dan mengambil tindakan untuk menguranginya dalam rangka pencapain tujuan organisasi. Efektivitas proses komunikasi dua arah di antara pimpinan dan pegawai adalah penting untuk mengidentifikasikan penyebab stres yang potensial dan pemecahannya.

Berdasarkan uraian di atas, dapatlah dikatakan bahwa permasalahan dalam bidang kepegawaian begitu kompleksnya. Sejalan dengan era otonomi daerah, maka permasalahan kepegawaian tersebut dapat menjadi hambatan bagi Daerah dalam mengemban amanat Undang-Undang maupun dalam upaya peningkatan daya saing 
(competitive advantages). Kondisi yang demikian akan menghambat kelancaran penyelenggaraan urusan pemerintahan, karena keterbatasan kualitas sumber daya yang dimiliki dalam pelaksanaan tugas dan fungsi organisasi perangkat daerah.

Sehubungan dengan hal tersebut, pengaruh stres kerja dan beban kerja pegawai yang dimiliki merupakan hal penting untuk dapat digunakan sebagai bahan pengambilan keputusan level manajemen dalam beragam pengembangan, baik kelembagaan, ketatalaksanaan, maupun sumberdaya manusia aparatur daerah.

Realisasi dari komitmen yang secara jelas dipaparkan dalam visi dan misi yang mengatasnamakan berbasis kinerja dan pelayanan publik diharapkan mampu menghapus pandangan negatif masyarakat tentang kinerja pemerintah daerah. Dari uraian tersebut menjadi permasalahan dalam penelitian ini adalah :

1. Apakah stres kerja berpengaruh terhadap kinerja SKPD Kabupaten Sintang Kalimanatan barat?

2. Apakah beban kerja berpengaruh terhadap kinerja SKPD Kabupaten Sintang Kalimanatan barat?

3. Apakah stres kerja dan beban kerja secara simultan berpengaruh terhadap kinerja SKPD Kabupaten Sintang Kalimantan Barat?

\section{TINJAUAN PUSTAKA}

A. Pengertian Stres Kerja

Menurut Desy (2002), stres kerja adalah suatu kondisi dimana satu atau beberapa faktor di tempat kerja berinteraksi dengan pekerja sedemikian rupa sehingga mengganggu keseimbangan fisiologik dan psikologik. Faktor-faktor tersebut misalnya beban kerja yang terlalu berat, pekerjaan yang terlalu sedikit, hubungan atasan bawahan yang kurang serasi dan peran yang tidak jelas. Stres merupakan hal yang lumrah dialami oleh setiap individu yang diakibatkan oleh faktor dari dalam maupun dari luardiri manusia itu sendiri. Stres bersifat fluktuasi kadang naik kadang turun tergantung dengan kondisi kerja yang dialami.

Menurut Sedarmayanti (2011:76), stres sering diartikan sebagai kelebihan tuntutan atas kemampuan individu dalam memenuhi kebutuhan. Masalah yang terdapat dalam lingkungan keluarga, kegiatan sosial, pekerjaan di kantor, kegiatan di waktu senggang, maupun yang ada hubungannya dengan orang lain, dapat menimbulkan beban yang berlebihan. Menurut Yusuf (2004:96) istilah stres tidak dapat dipisahkan dari distressdan depresi, karena satu sama lainnya saling terkait. Stres merupakan reaksi fisik terhadap permasalahan kehidupan yang dialaminya dan apabila fungsi organ tubuh sampai terganggu dinamakan distress. Sedangkan depresi merupakan reaksi kejiwaan terhadap stres seseorang yang dialaminya.

Romli (2010), mengemukakan bahwa stres merupakan suatu tekanan akibat bekerja juga akan mempengaruhi emosi, proses berpikir dan kondisi fisik seseorang, dimana tekanan itu berasal dari lingkungan pekerja tempat individu tersebut berada. 
Menurut Agung (2008) stres adalah tuntutan-tuntutan eksternal yang mengenai seseorang, misalnya obyek-obyek dalam lingkungan atau suatu stimulus yang secara obyektif adalah berbahaya. Stres juga biasa diartikan sebagai tekanan, ketegangan atau gangguan yang tidak menyenangkan yang berasal dari luar diri seseorang.

\section{B. Faktor - Faktor Penyebab Stres}

Menurut Gibson et al.,(1996), stres kerja terjadi pada diri pegawai sebetulnya bukan hanya karena konflik saja tetapi faktor-faktor lain yang mempengaruhi, diantaranya: (1) kekaburan peran dan konflik peran, (2) kelebihan beban kerja, (3) tanggung jawab atas orang lain, (4) perkembangan karir, (5) kurangnya kohesi kelompok, (6) dukungan kelompok yang tidak memadai, (7) karakteristik tugas, (8) pengaruh kepemimpinan.

Menurut International Labour Organization (ILO) dalam Rheda (2008:9), faktor lingkungan yang mempengaruhi stres kerja antara lain adalah :

a. Faktor Lingkungan Fisik antara lain : penggunaan cahaya penerangan, bau yang menusuk hidung,suhu panas atau dingin, jauhnya jarak rumah ketempat kerja, sarana transportasi tidak memadai, yang memaksa pekerja menghabiskan waktunya dalam perjalanan untuk berganti-ganti kendaraan umum dan berdesak-desakan di dalamnya

b. Faktor Lingkungan Sosial antara lain :

- Beban kerja yang berlebihan, seperti terlalu banyaknya pekerjaan, rutinitas pekerjaan sementara tuntutan pekerjaan berlebihan dan rendahnya perhatian atasan, rendahnya kualitas beban kerja antara lain lingkungan kerja kurang memberikan variasi sehingga menurunkan kualitas beban kerja karena kelelahan para pegawai, kurangnya tuntutan kreatifitas para pegawai

- Kurangnya dukungan sosial dari teman-teman dan keluarga di rumah.

- Shift kerja tidak teratur

- Live events (kejadian-kejadian dalam kehidupan sehar-hari). Perubahan yang terjadi dalam kehidupan individu menjadikannya rentan terhadap stres bila ia tidak dapat beradaptasi dengan kejadian itu.

- Dukungan sosial keluarga dan teman dekat.

c. Faktor Pekerja. Faktor pekerja meliputi adanya konflik peran (orang yang memiliki beberapa peran yang saling bertentangan), tidak jelasnya tugas dan tanggung jawab yang terlalu tinggi terhadap tugas, dan adanya desakan waktu penyelesaian tugas. Demikian juga faktor kerja kelompok seperti norma-norma yang dianut dalam kelompok yang harus dipatuhi anggotanya, kurangnya kekompakam diantara anggota kelompok dankurangnya dukungan kelompok (Redha, 2008:11).

\section{Pengaruh dan Efek Samping Stres Kerja}

Menurut Jacinta (2002) dalam Septianto (2010) stres kerja dapat juga mengakibatkan hal-hal sebagai berikut: 
Dampak terhadap perusahaan :

1. Terjadinya kekacauan, hambatan baik dalam manajemen maupun operasional kerja

2. Mengganggu kenormalan aktivitas kerja

3. Menurunnya tingkat produktivitas

4. Menurunkan pemasukan dan keuntungan perusahaan.

Demikian pula jika banyak diantara tenaga kerja di dalam organisasi atau perusahaan mengalami stres kerja, maka produktivitas dan kesehatan organisasi itu akan terganggu. Anggapan tentang stres kebanyakan menuju pada hal yang negatif, seperti suatu kondisi yang mengarah ke timbulnya penyakit fisik maupun mental, atau mengarah ke perilaku yang tidak wajar. Stres tidak selaludipandang sebagai hal yang negatif. Apabila dimanfaatkan dengan baik, stres dapat meningkatkan prestasi kerja.

\section{Manajemen Stres}

Dalam menanggulangi stres yang terjadi pada pegawai, banyak hal-hal yang dapat dilakukan. Agung (2008), mengatakan bahwa dari sudut pandang organisasi, manajemen mungkin tidak khawatir jika pegawainya mengalami stres yang ringan. Alasannya karena pada tingkat stres tertentu akan memberikan akibat positif, karena hal ini akan mendesak mereka untuk melakukan tugas lebih baik. Tetapi pada tingkat stres yang tinggi atau stres ringan yang berkepanjangan akan membuat menurunnya kinerja pegawai. Stres ringan mungkin akan memberikan keuntungan bagi organisasi, tetapi dari sudut pandang individu hal tersebut bukan merupakan hal yang diinginkan. Maka manajemen mungkin akan berpikir untuk memberikan tugas yang menyertakan stres ringan bagi pegawai untuk memberikan dorongan bagi pegawai, namun sebaliknya itu akan dirasakan sebagai tekanan oleh si pekerja. Maka diperlukan pendekatan yang tepat dalam mengelola stres, ada dua pendekatan yaitu pendekatan individu dan pendekatan organisasi.

\section{E. Pengertian Beban Kerja}

Menurut Permendagri No. 12/2008, beban kerja adalah besaran pekerjaan yang harus dipikul oleh suatu jabatan atau unit organisasi dan merupakan hasil kali antara volume kerja dan norma waktu. Robbins (2003:90), menyatakan bahwa positif negatifnya beban kerja merupakan masalah persepsi. Persepsi didefinisikan sebagai suatu proses dimana individu mengorganisasikan dan menafsirkan kesan indera mereka agar memberi makna kepada lingkungan mereka (Robbins, 2007:160). Persepsi terhadap beban kerja berkaitan dengan faktor atribut peran dan pekerjaan. Hal ini dikarenakan persepsi terhadap beban kerja merupakan hal yang erat hubungannya dengan suatu pekerjaan, dimana individu memberikan penilaian mengenai sejumlah tuntutan atau kegiatan yang membutuhkan aktivitas mental dan fisik yang harus ia selesaikan dalam waktu tertentu, apakah memiliki dampak positif atau negatif terhadap pekerjaannya. 
Dalam penelitian ini indikator beban kerja yang digunakan mengadopsi indikatorbeban kerja yang digunakan dalam penelitian yang telah dilakukan oleh Putra (2012:22) yang meliputi antara lain :

1. Target yang harus dicapai

Pandangan individu mengenai besarnya target kerja yang diberikan untuk menyelesaikan pekerjaannya, misalnya untuk menggiling, melinting, mengepak dan mengangkut. Pandangan mengenai hasil kerja yang harus diselesaikan dalam jangka waktu tertentu.

\section{Kondisi Pekerjaan}

Mencakup tentang bagaimana pandangan yang dimiliki oleh individu mengenai kondisi pekerjaannya, misalnya mengambil keputusan dengan cepat pada saat pengerjaan barang, serta mengatasi kejadian yang tak terduga seperti melakukan pekerjaan ekstra diluar waktu yang telah ditentukan.

3. Standar Pekerjaan

Kesan yang dimiliki oleh individu mengenai pekerjaannya, misalnya perasaan yang timbul mengenai beban kerja yang harus diselesaikan dalam jangka waktu tertentu.

F. Faktor-faktor yang Mempengaruhi Beban Kerja

Rodahl (1989) dalam Prihatini (2007:25), menyatakan bahwa beban kerja dipengaruhi faktor-faktor sebagai berikut :

1. Faktor eksternal yaitu beban yang berasal dari luar tubuh pekerja, seperti :

a. Tugas -tugas yang dilakukan yang bersifat fisik seperti stasiun kerja, tata ruang tempat kerja, alat dan sarana kerja, kondisi kerja, sikap kerja, sedangkan tugastugas yang bersifat mental seperti kompleksitas pekerjaan, tingkat kesulitan pekerjaan, pelatihan atau pendidikan yang diperoleh, tanggung jawab pekerjaan.

b) Organisasi kerja seperti masa waktu kerja, waktu istirahat, kerja bergilir, kerja malam, sistem pengupahan, model struktur organisasi, pelimpahan tugas dan wewenang.

c) Lingkungan kerja adalah lingkungan kerja fisik, lingkungan kimiawi, lingkungan kerja biologis, dan lingkungan kerja psikologis.Ketiga aspek ini disebut wring stresor.

\section{Faktor Internal}

Faktor internal adalah faktor yang berasal dari dalam tubuh akibat dari reaksi beban kerja eksternal. Reaksi tubuh disebut strain, berat ringannya strain dapat dinilai baik secara objektif maupun subjektif. Faktor internal meliputi faktor somatis (jenis kelamin, umur, ukuran tubuh, status gizi, kondisi kesehatan), faktor psikis (motivasi, persepsi, kepercayaan. keinginan dan kepuasan). 


\section{G. Pengertian Kinerja}

Menurut Bastian (2006:274), kinerja adalah gambaran pencapaian pelaksanaan suatu kegiatan/program /kebijaksanaan dalam mewujudkan sasaran, tujuan, misi, dan visi organisasi. Secara umum, kinerja merupakan prestasi yang dicapai oleh organisasi dalam periode tertentu. Lebih lanjut kinerja adalah hasil kerja secara kualitas dan kuantitas yang dicapai oleh seorang pegawai dalam melaksanakan tugasnya sesuai dengan tanggung jawab yang diberikan kepadanya (Mangkunegara, 2005:9).

Pendapat serupa dikemukakan oleh Melayu (2009:93) dalam Redha (2008), yang menyatakan bahwa kinerja adalah suatu hasil kerja yang dicapai seseorang dalam melaksanakan tugas - tugas yang dibebankan kepadanya atas kecakapan, pengalaman, dan kesungguhan serta waktu. Pribadi yang produktif akan lebih kreatif dalam berhubungan dengan dunia sekitarnya dengan cara meciptakan suatu hasil kerja melalui kemampuan dan menggunakan pikiran serta perasaannya. Individu yang kreatif dapat dikatakan sebagai seseorang yang tinggi independensinya, inovatif dalam pendekatan masalah, terbuka terhadap suatu pengalaman baru yang lebih luas, ditandai dengan spontanitas, fleksibilitas, dan kompleksitas pandangan (Sedarmayanti, 2009:82).

Dari penjelasan diatas dapat disimpulkan bahwa kinerja adalah suatu pencapaian ataupun hasil kerja yang diperoleh dari seseorang dalam melaksanakan tugas dantanggung jawabnya sesuai dengan kriteria yang telah ditetapkan oleh suatu organisasi dengan waktu yang telah ditetapkan.

Novitasari (2003:22), mengemukakan bahwa tingkat sejauh mana keberhasilan seseorang dalam menyelesaikan pekerjaannya disebut "level of performance". Biasanya orang yang level performance-nya tinggi disebut sebagai orang yang produktif, dan sebaliknya orang yang levelnya tidak mencapai standar dikatakan sebagai tidak produktif atau perormance-nya rendah.

Menurut Sami'an (2008), penilaian kinerja merupakan suatu sistem formal yang secara berkala digunakan untuk mengevaluasi kinerja individu dalam menjalankan tugas-tugasnya. Penilaian kinerja (performance appraisal) adalah proses evaluasi seberapa baik staf atau pegawai mengerjakan pekerjaan mereka ketika dibandingkan dengan satu set standar, dan kenudian mengkomunikasikannya dengan para staf (Redha, 2008:25).

\section{H. Hipotesis}

Berdasarkan permasalahan yang telah dikemukakan sebelumnya, maka penulis merumuskan hipotesis sebagai berikut:

$\mathrm{H}_{1}$ : Stres kerja berpengaruh terhadap kinerja pegawai

$\mathrm{H}_{2}$ : Beban kerja berpengaruh terhadap kinerja pegawai.

$\mathrm{H}_{3}$ : Stres kerja dan beban kerja secara simultan berpengaruh terhadap kinerja pegawai 


\section{Kerangka Pikir}

Sumber daya manusia dalam hal ini pegawai dalam organisasi merupakan aset yang paling penting dalam menunjang keberhasilan tujuan suatu organisasi. Oleh karena itu organisasi harus memperhatikan kemampuan yang dimiliki oleh setiap pegawainya. Kinerj aadalah pencapaian hasil kerja secara kualitas dan kuantitas yang dicapai oleh seorang karyawan dalam melaksanakan tugasnya sesuai dengan tanggung jawab yang diberikan kepadanya.

Penelitian ini meliputi atribut kinerja SKPD sebagai variabel yang akan diukur dengan melihat pengaruh interaksi antara stres kerja dan beban kerja terhadap kinerja SKPD Kabupaten Sintang Kalimantan Barat. Dimana variabel stres kerja dan beban kerja adalah variabel independen (bebas) sedangkan kinerja SKPD adalah variabel dependen (terikat). Dari kerangka teoritis tersebut akan dilihat pengaruh stres kerja terhadap kinerja SKPD Kabupaten Sintang Kalimantan Barat dan pengaruh beban kerja terhadap kinerja SKPD Kabupaten Sintang Kalimantan Barat.

Gambar 1.

Kerangka Pemikiran

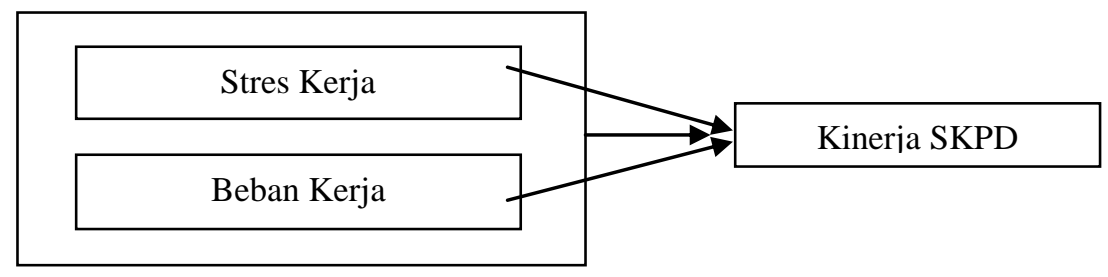

\section{METODE PENELITIAN}

A. Variabel dan Definisi Operasional

1. Variabel

Variabel merupakan gejala yang menjadi fokus penelitian untuk diamati. Variabel tersebut sebagai atribut dari sekelompok obyek yang mempunyai variasi antara satu dengan lainnya dalam kelompok itu (Suharsimi Arikunto, 2000). Dalam penelitian ini ada dua jenis variabel dimana variabel stres kerja dan beban kerja adalah variabel independen (bebas) meliputi konflik kerja, waktu kerja, karakterisik tugas, dan pengaruh kepemimpinan. Sedangkan kinerja SKPD adalah variabel dependen (terikat).

2. Karakteristik responden

Karakteristik responden dilihat dari variabel jenis kelamin, usia, pendidikan, lama bekerja. Pengukurannya menggunakan skala linkert dengan lima pilihan jawaban, yaitu Sangat Tidak Setuju (STS), diberi nilai 1, Tidak Setuju (TS) diberi nilai 2, Netral (N) diberi nilai 3, Setuju (S) diberi nilai 4, dan Sangat Setuju (SS) diberi nilai 5.

\section{B. Populasi dan Sampel}

Menurut Sugiyono (2008), pengertian populasi adalah wilayah generalisasi yang terdiri atas objek/subjek yang mempunyai kuantitas dan karakteristik tertentu yang ditetapkan oleh peneliti untuk dipelajari. Jadi populasi bukan hanya orang, tetapi juga 
benda - benda alam yang lain. populasi juga bukan sekedar jumlah yang ada pada objek/subjek yang dipelajari, tetapi meliputi seluruh karakteristik/sifat yang dimiliki oleh objek atau subjek itu. Survei sampel adalah suatu prosedur yang hanya sebagian dari populasi saja yang diambil dan dipergunakan untuk menentukan sifat serta ciri yang dikehendaki dari populas. Populasidalam penelitian ini adalah SKPD pemerintah daerah kabupaten Sintang Kalimantan Barat. Sedangkan sampel yang digunakan yaitu keseluruhan SKPD pada pemerintah daerah Kabupaten Sintang Kalimantan Barat dengan jumlah 75 responden.

\section{Metode Pengumpulan Data}

Sumber data yang digunakan dalam penelitian ini yaitudata primerdan data sekunder. Menurut Umar dalam Atmaji (2011), data primer merupakan data yang didapat dari sumber pertama baik dari individu atau perseorangan, seperti hasil wawancara atau pengisian kuesioner. Sedangkan data sekunder dalam penelitian ini sebagi pelengkap data primer berupa keterangan - keterangan, catatan - catatan, maupun teori-teori yang mendukung penelitian ini.

\section{Uji Validitas dan Reabilitas \\ 1. Uji Validitas}

Pengujian validitas ini dilakukan dengan menghitung korelasi antara skor item instrumen dengan skor total. Nilai koefisien korelasi antara skor setiap item dengan skor total dihitung dengan analisis corrected item-total correlation. Suatu instrumen dinyatakan valid apabila koefisien korelasi $r$ hitung lebih besar dibandingkan koefisien korelasi $r$ tabel pada taraf signifikansi 0,05 .

Nilai $r$ tabel dapat dilihat pada tabel $r$ statistik dengan $n=75$ atau $\mathrm{df}=\mathrm{n}-2=73$ dan dengan tingkat signifikansi 0,05 maka didapat nilai $r$ tabel $=0,3160$ sedang untuk konflik kerja 0, 630; waktu kerja $=0,753$; karakteristik tugas $=0,533$; pengaruh kepemimpinan $=0,654$. Karena semua item memiliki $r$ hitung $>r$ tabel $(0,3160)$ maka semua item dinyatakan valid.

\section{Uji Reabilitas}

Uji reabilitas digunakan untuk mengetahui konsistensi alat ukur, apakah alat ukur yang digunakan dapat diandalkan dan tetap konsisten jika pengukurannya tersebut diulang. Pengujian reliabilitas yang digunakan adalah dengan menggunakan metode Cronbach Alpha. Metode ini digunakan untuk mencari nilai dan bentuk skala. Suatu variabel dikatakan reliabel jika nilai Cronbach Alpha > 0,60 (Ghozali, 2005) :

- Jika nilai Cronbach Alpha > 0,60 maka kuesioner yang diuji dinyatakan reliabel

- Jika nilai Cronbach Alpha $<0,60$ maka kuesioner yang diuji dinyatakan tidak reliabel 
Dengan penghitungan program SPSS maka didapat nilai reabilitas untuk masing masing variabel stres kerja $=0,737$; beban kerja $=0,765 ;$ kinerja pegawai = 0,751.Karena nilai Cronbach Alpha diatas 0,60 maka alat ukur tersebut reliabel atau telah memenuhi syarat reabilitas.

\section{Analisis Statistik}

a. Analisis Deskripsi Kategori Variabel

1. Stres Kerja

Hasil analisis deskriptif pada variabel kepuasan kerjadiperoleh nilai minimum sebesar 59,00, nilai maksimum sebesar83,00, nilai mean 70,0870, nilai standar deviasi 0,4916. Selanjutnya data kepuasan kerja dikategorikan dengan menggunakan skor rata-rata (M) dan simpangan baku (SD). Dari hasil pengujian di dapat mayoritas responden memberikan penilaian terhadap variable stress kerja dalam kategori sedang yaitu sebanyak 32 responden $(42,7 \%)$, responden yang memberikan penilaian terhadap variabel stress kerja dalam kategori tinggi sebanyak 28 responden (37,3\%), dan responden yang memberikan penilaian terhadap variabel stress kerja dalam kategori rendah sebanyak 15 responden (20\%). Dapat disimpulkan bahwa sebagian besar responden mengalami unsur unsur stress kerja terhadap pekerjaan yang ada pada SKPD Kabupaten Sintang Kalimantan Barat.

\section{Beban Kerja}

Hasil analisis deskriptif pada variabel beban kerja diperolehnilai minimum sebesar 25,00, nilai maksimum sebesar 41,00, nilai mean 31,7717, nilai standar deviasi 0,2559. Dari pengujian terlihat bahwa mayoritas responden memberikan penilaian terhadap variabel beban kerja dalam kategori sedang yaitu sebanyak 33 responden $(44 \%)$, responden yang memberikan penilaian terhadap variabel beban kerja dalam kategori rendah sebanyak 25 responden $(33,33 \%)$, dan responden yang memberikan penilaian terhadap variabel beban kerja dalam kategori tinggi sebanyak 14 responden $(18,67 \%)$. Dapat disimpulkan bahwa sebagian besar responden merasa tercukupi dengan beban kerja yang diterapkan oleh masingmasing bagian pada SKPD Kabupaten Sintang Kalimantan Barat.

\section{Kinerja SKPD}

Hasil analisis deskriptif pada variabel kinerja karyawandiperoleh nilai minimum sebesar 25,00, nilai maksimum sebesar36,50, nilai mean 30,5598, nilai standar deviasi 0,2167. Dari pengujian terlihat bahwa mayoritas responden memberikan penilaian terhadap variabel kinerja karyawan dalam kategori sedang yaitu sebanyak 41 responden $(54,7 \%)$, responden yang memberikan penilaian terhadap variabel kinerja karyawan dalam kategori tinggi sebanyak 23 responden $(30,7 \%)$, dan responden yang memberikan penilaian terhadap variabel kinerja karyawan dalam kategori rendah sebanyak 11 responden $(14,6 \%)$. 
b. Uji t

Tabel 1

Coefficient $^{\mathrm{a}}$

\begin{tabular}{|c|c|c|c|c|c|}
\hline Model & $\begin{array}{l}\text { Unstandardized } \\
\text { Coefficients }\end{array}$ & & $\begin{array}{l}\text { Standardized } \\
\text { Coefficient }\end{array}$ & $\mathrm{T}$ & Sig \\
\hline & 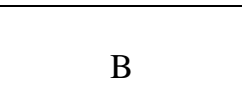 & $\begin{array}{l}\text { Std. } \\
\text { Error }\end{array}$ & Beta & & \\
\hline $\begin{array}{ll}1 & \text { (Constant) } \\
& \text { X1 } \\
& \text { X2 }\end{array}$ & $\begin{array}{r}13,952 \\
, 331 \\
, 460\end{array}$ & $\begin{array}{r}6,936 \\
, 074 \\
, 058\end{array}$ & $\begin{array}{l}, 642 \\
, 806\end{array}$ & $\begin{array}{l}2,012 \\
3,419 \\
7,984\end{array}$ & $\begin{array}{l}, 052 \\
, 028 \\
, 000\end{array}$ \\
\hline
\end{tabular}

Sumber : Data diolah SPSS (2015)

Uji Regresi Linier Berganda diperoleh sebagai berikut :

$$
\mathrm{Y}=13,952+0,331 \mathrm{X}_{1}+0,460 \mathrm{X}_{2}
$$

Berdasarkan hasil regresi yang ada, uji t dilakukan dengan membandingkan nilai $t_{\text {hitung }}$ dengan $t_{\text {tabel }}$ dengan tingkat kesalahan 5\% yakni 1,685. Apabila $t_{\text {hitung }}>t_{\text {tabel }}$ maka dapat disimpulkan variabel tersebut mempunyai pengaruh yang signifikan.

1. Variabel Stres Kerja $\left(\mathrm{X}_{1}\right)$

Nilai $t_{\text {hitung }}$ untuk variabel ini sebesar 3,419. Sementara itu nilai pada tabel distribusi $5 \%$ sebesar 1,685. Maka $t_{\text {hitung }}(3,419)>t_{\text {tabel }}(1,685)$ dan nilai signifikansi $(0,028<$ $0,050)$ artinya variabel stres kerja $\left(\mathrm{X}_{1}\right)$ berpengaruh positif dan signifikan terhadap kinerja pegawai. Jadi, $\mathrm{H}_{1}$ di terima. Hal ini menunjukkan bahwa stres kerja yang dialami oleh SKPD Kabupaten Sintang Kalimantan Barat dikatakan ringan atau cukup. Dimana ketika stres kerja ringan atau cukup, maka stres kerja dapat membantu SKPD untuk mengarahkan segala sumber daya dalam memenuhi kebutuhan kerja.

2. Variabel Beban Kerja $\left(\mathrm{X}_{2}\right)$

Nilai $t_{\text {hitung }}$ untuk variabel ini sebesar 7,984. Sementara itu nilai pada tabel distribusi $5 \%$ sebesar 1,685. Maka $t_{\text {hitung }}(7,984)>t_{\text {tabel }}(1,685)$ dan nilai signifikansi $(0,000<$ $0,050)$ artinya variabel beban kerja $\left(\mathrm{X}_{2}\right)$ berpengaruh positif dan signifikan terhadap kinerja pegawai. Jadi, $\mathrm{H}_{2}$ diterima. Hal ini menunjukkan, ketika seseorang memiliki beban kerja yang tinggi, maka akan menghasilkan kinerja yang tinggi pula dalam bekerja.

c. Uji F

Uji statistik F dilakukan untuk mengetahui apakah semua variabel independen yang dimasukkan dalam model mempunyai pengaruh signifikan secara bersama - sama terhadap variabel dependen. Atau untuk mengetahui apakah model regresi dapat digunakan untuk memprediksi variabel dependen atau tidak. Pengujian dilakukan dengan membandingkan nilai $F_{\text {hitung }}$ dengan $F_{\text {tabel }}$ pada derajat kesalahan 5\% $(\alpha=0.05)$. Apabila nilai $F_{\text {hitung }} \geq$ dari nilai $F_{\text {tabel}}$, maka berarti variabel bebasnya secara serempak memberikan pengaruh yang bermakna terhadap variabel terikat. 


\begin{tabular}{|c|c|c|c|c|c|c|}
\hline & \multicolumn{6}{|c|}{$\begin{array}{c}\text { Tabel } 2 \\
\text { Uji F }\end{array}$} \\
\hline & \multirow[t]{2}{*}{ Model } & Sum of & & Mean & & \\
\hline & & Squares & Df & Square & F & Sig \\
\hline 1 & Regression & 642,849 & 2 & 321,424 & 37,299 & ,000(a) \\
\hline & Residual & 310,228 & 36 & 8,617 & & \\
\hline & Total & 953,077 & 38 & & & \\
\hline
\end{tabular}

Sumber : Data diolah SPSS 2015

Hasil yang diperoleh untuk $F_{\text {tabel }}$ adalah sebesar 3,26. Hal ini berarti $F_{\text {hitung }}$ lebih besar dari pada $\mathrm{F}_{\text {tabel }}(37,299>3,26)$. Perhitungan tersebut menunjukkan bahwa stres kerja dan beban kerja secara bersama-sama berpengaruh positif dan signifikan terhadap kinerja pegawai. Jadi, $\mathrm{H}_{3}$ dapat di diterima.

\section{KESIMPULAN DAN SARAN}

\section{A. Kesimpulan}

1. Hasil penelitian ini berhasil mendukung hipotesis pertama $\left(\mathrm{H}_{1}\right)$, yaitu variabel stres kerja $\left(\mathrm{X}_{1}\right)$ berpengaruhterhadap kinerja pegawai/SKPD (Y). Hal ini menunjukkan bahwa sejalan dengan meningkatnya streskerja, prestasi kerja cenderung naik, karena stres kerja dapat membantuuntuk mengarahkan segala sumber daya dalam memenuhi kebutuhan kerjabegitupun sebaliknya.

2. Hasil penelitian untuk hipotesis kedua $\left(\mathrm{H}_{2}\right)$ berhasil,yaituvariabel motivasi kerja $\left(\mathrm{X}_{2}\right)$ berpengaruh terhadap kinerja pegawai $(\mathrm{Y})$. Jadi beban kerja ini sangat mempengaruhi kinerja pegawai. Ketika seseorang memiliki beban kerja yang tinggi, maka akan memiliki kinerja yang tinggi pula dalam bekerja.

3. Pengujian hipotesis yang terkahir $\left(\mathrm{H}_{3}\right)$ juga mendukung hipotesis yang diajukan, dimana variabel stres kerja dan beban kerja secara simultan berpengaruh terhadap kinerja SKPD Kabupaten Sintang Kalimantan Barat. Dari hasil penelitian ini membuktikan bahwa ketika seseorang memiliki beban kerja yang tinggi maka akan meningkatkan kinerja pegawai, begitupunketika pegawai memiliki stres kerja yang tidak terlalu tinggiatau cukupmaka dapat mendorong pegawai SKPD Kabupaten Sintang Kalimanatan Barat untuk mmenyelesaikan tugas dan tanggung jawabnya dalam bekerja.

B. Saran

1. Penelitian selanjutnya diharapkan memilih variabel lain yang dapat meningkatkan kinerja pegawai pada suatu instansi misalnya: kepuasan kerja, budaya kerja, kompensasi, reward, dan kepribadian. 
2. Dalam rangka meningkatkan motivasi kerja terhadap kinerja SKPD Kabupaten Sintang Kalimantan Barat maupun instansi lainnya, maka disarankan agar memberikan penghargaan bagi pegawai - pegawaiyang berprestasi.

\section{DAFTAR PUSTAKA}

Agung. 2008. Stres kerja (pengertian dan pengenalan) (online),http://agungpia.multiply.com/journal/item/35/Stress_Kerja_pengertian_d an_pengenalan?\&show_interstitial $=1 \& \mathrm{u}=\% 2$ Fjournal $\% 2$ Fitemdiakses tanggal 08 November 2012

Arikunto, Suharsimi. 1998. Prosedur Penelitian Suatu Pendekatan Praktek. Jakarta: PT.Rineka Cipta

Atmaji, Luthfan. 2011. Pengaruh Stres Kerja dan Kepuasan Kerja terhadap Kinerja Perawat (Studi pada Rumah Sakit Islam Sultan Agung Semarang). Skripsi. FakultasEkonomi Universitas Diponegoro, Semarang

Bastian, Indra, 2006, Akuntansi Sektor Publik: Suatu Pengantar, Erlangga, Jakarta

Desy, Vita Helia. 2002. Tingkat Stres Kerja dan Faktor-Faktor yang Berhubungan Dengan Stres Kerja pada Karyawan Bagian Marketing Services PT Unilever Indonesia Tbk. Skripsi. Program Sarjana Kesehatan Masyarakat. Universitas Indonesia

Ghozali, Imam. 2005. Aplikasi Analisis Multivariate Dengan Program SPSS. Edisi Kedua. Semarang: Badan Penerbit Universitas Diponogoro.

Gibson, Ivancevich, Donnelly. 1996. Organisasi. Jilid I. Edisi ke Delapan. Jakarta:Binarupa Aksara.

Mangkunegara, A.A Anwar Prabu.2005. Evaluasi Kinerja Sumber Daya Manusia.Bandung: Refika Aditama

Malayu, S. P. Hasibuan, 2006. Manajemen Sumber Daya Manusia. Edisi Revisi, Cetakan Kedelapan, Jakarta: Bumi Aksara

Novitasari Andraeni, Ni Nyoman, 2003, Pengaruh Stres Kerja terhadap Motivasi Kerja dan Kinerja Karyawan PT. H.M Sampoerna Tbk Surabaya, Tesis, Surabaya: Program Pasca Sarjana Universitas Airlangga

Redha, A. Achmad. 2008. Pengaruh Stres Kerja dan Motivasi Kerja terhadap Kinerja Staf Keungan Dinas Di Kabupaten Majene Sulawesi Barat,skripsi. FakultasEkonomi Universitas Hasanuddin, Makassar 